\title{
HuMPTY DuMPTY POPULISM
}

\author{
Theopolitics and the Retreat of the Politico-theological \\ in Venezuela (and Elsewhere)
}

Rafael Sánchez

\begin{abstract}
This article analyzes Venezuelan Chavismo as an unstable formation gnawed by the unsolvable contradiction between, on the one hand, the politico-theological ambition to totalize sociality as a visible 'people' collected around the invisible 'Spirit' of Venezuela's 'Founding Father' Simón Bolívar and, on the other, the non-totalizable theopolitical energies of a social field suffused with myriad globalized 'spirits' that admits no clear-cut demarcation between 'visible' and 'invisible' or 'material' and 'spiritual'. Incapable of totalizing sociality as a discrete 'society', the political logic informing Chavismo, as with other recent populisms, shifts from hegemony to 'dominance without hegemony', a situation where, à la Humpty Dumpy, the 'people' is whatever is 'lovingly' decreed as such from above, always in tension with a host of deconstructive, often theopolitically imbued agencies and spirits.
\end{abstract}

Keywords: body, Chavismo, crowds, mimesis, political theology, populism, spirit possession, theopolitics

"Good morning Venezuela, we have a Constituent Assembly ... in the midst of threats ... defying the bullets of the paramilitary more than 8 million Venezuelans crossed rivers, traversed mountains to cast their ballots in favor of this new assembly" (Luigino Bracci 2017). ${ }^{1}$ With these words announcing the tally of the Venezuelan national election on 31 July 2017, the current president of Venezuela, Nicolás Maduro Moros, proclaimed that his party, the Partido Socialista Unido de Venezuela (PSUV), had been re-elected with a strong majority and mandate to radically reorder Venezuelan society. Speaking at a televised press conference in London just two days after Maduro's declaration, Antonio Mugica, the spokesperson for Smartmatic, the company that had provided the 
electronic platform for tallying the vote in Venezuelan elections since 2004, flatly contradicted the president: "We know without a doubt that the result of the recent elections for a National Constituent Assembly were manipulated," adding "we estimate that the difference between actual and announced participation by the authorities is at least one million votes" (Reuters Staff 2017).

From a purely numeric standpoint, Maduro's claimed victory flew in the face of available evidence; ${ }^{2}$ from a political point of view, however, his proclamation, and its apparent mendacity, is not straightforward. Maduro's contempt for the 'facts' is itself highly revealing, or so I argue, of the kind of post-truth populism into which a revolutionary project like Chavismo mutates when subject to conditions of intense neoliberal globalization. ${ }^{3}$ According to such a Humpty Dumpty populist revolutionary logic ("a word ... means just what I choose it to mean," said Humpty Dumpy to Alice in Alice Through the Looking Glass), regardless of any evidence, numerical or otherwise, not only is 'the people' a homogeneous entity, in line with the official rhetoric that often pits it against an ill-defined 'civil society' made of middle-class enemies of the regime, this 'people' is necessarily and exclusively Chavista. By this logic, the vast majority of the population, that is, the Chavista 'people', will always remain solidly behind el gobierno del pueblo (the government of/by the people) with Nicolás Maduro at the helm, decisively casting their ballots for any of the government's initiatives for no other reason than because either the president or some other member of the government unilaterally proclaims all this to be the case. The rest, the non-people, simply do not count.

Just in case Maduro's declaration is seen as typical Latin American hyperbole, any number of similar pronouncements by Donald Trump are every bit as reckless. A glaring instance of this recklessness was when, against all evidence, Trump claimed that the crowds at his inauguration were the largest ever for this sort of event. For Trump, as much as for Maduro, regardless of any actual numbers, 'the people' is simply that which, in truly Humpty Dumpty fashion, they designate as such from above, and such a people, by definition the majority, is always behind them. The rest, the non-people or the anti-people, no matter how sizable or vast, are simply those targeted for either subjection or elimination. While at least since the French Revolution "declarations of the 'people' are always performative and exclusive," 4 what seems to be novel in the kind of Humpty Dumpty or post-truth populism that I address here is that this performative quality is starkly revealed: regardless of all the grandiose claims about the people's universality, this claim lacks plausibility. For the most part, no one really believes that the 'people' of the recent populist regimes stands for anything other than an increasingly tribalized partiality.

I view the discrepancy between Maduro's and Mugica's competing proclamations as symptomatic of the kind of post-truth populisms that, in Venezuela and elsewhere, have emerged in recent years in response to the current 
conditions of heightened neoliberal globalization. ${ }^{5}$ I argue in this article that, regardless of all the claims on the part of these recent populisms to 'truly' and 'democratically' represent a popular consensus, in contrast to older populist formations, the overall significance and directionality of these more recent political movements and regimes in the end have little to do with the question of democracy. Contrary to what is often assumed, these recent populisms including Chavismo are not 'illiberal democracies' in Fareed Zakaria's (2003) sense of authoritarian regimes where a political sector rules through the orchestration and manipulation from above of the democratically elected majorities, pitting them as a 'true people' against the nation's minorities.

Indeed, while such a manipulation of the democratically elected majorities may be contingently present, what is characteristic of these movements is something else. That which imbues them with their intrinsic logic and directionality is, first, their state-centered, properly politico-theological, totalizing project to bring about revolution, that is, a radical transformation of the entire social order of the nation-state at all costs, regardless of whether at any given time they count or do not count on the democratic support of the majorities. Much as in the case of Trump's crowds, often it would seem that, forced on account of the nominally democratic frame within which they operate to pay lip service to the question of democracy, it suffices for these post-truth populisms to insistently proclaim that such a democratic support is, indeed, there for such a claim to be non-problematically paraded as the truth. Meanwhile, if at any given time the actual majorities happen to oppose the regime, every available means is shamelessly mobilized in order to prevent them from effectively exercising their rights at the booth. While the word 'democracy' is often invoked, in fact very little effort is made to disguise as democratic those processes that have more to do with open warfare of one sector of society against the other than with any actual democracy, however one wishes to understand this term. The second element that must be taken into account is the fact that, for reasons to be clarified, this single-minded revolutionary project is carried out under neoliberal conditions that are, however, highly resilient to any such hubristically totalizing ambitions.

In limiting myself to Chavismo, I mean to illustrate two points. First, that in line with its radical Bolivarian political theology, this political movement is bent on reducing by whatever means, regardless of whether they are democratic, Venezuelan sociality to a seamless, homogeneous whole, a governable 'people' collected around the 'invisible' Spirit of the Liberator Simón Bolívar, Venezuela's dead Founding Father and this political movement's presiding tutelary deity. ${ }^{6}$ As with any other political theology, to be successful this reductive operation calls for the institution of a radical partition or demarcation between the 'visible' and the 'invisible', the material and the spiritual, or, what amounts here to the same, between, on the one hand, Bolívar's agentive 
Spirit as incarnated in the Bolivarian state and the figure of Chavez as Bolívar's earthly lieutenant, and, on the other, a Venezuelan sociality devoid of any transcendence, agency, or spirituality of its own that, ultimately, is not fully identical with and subsumed by that of the state. ${ }^{7}$ If this does not happen and rather than bereft of Spirit the world is, instead, plethoric with pluralized spirits capable of acting on their own, according to their own peculiar and often quirky whims and designs, then the pretension of this Bolivarian state to repeatedly institute in the exception a fully present totality, a substantially homogeneous 'people' possessed by the Spirit of the Liberator misfires. Put otherwise, if the world continues to insist on its radical plurality and undecidability, a situation where no clear-cut demarcation between the 'visible' and the 'invisible' or the 'spiritual' and the 'material' ever obtains, at least not immanently, the Bolivarian state's politico-theological project of totalizing sociality as a discrete 'people' or 'society' fully subjected to its sovereign decisions and dictates runs aground and, instead, something else happens.

At the present time, Venezuelan sociality-especially in the wake of a neoliberal adjustment program imposed by the International Monetary Fund (IMF) in the early 1990s, of which I will have more to say, and the thorough deinstitutionalization that it instigated-is precisely the kind of spiritually haunted milieu where any politico-theological project, no matter how ambitious, fatefully runs aground. If theopolitics alludes to "the capacity for divine action through processes of withdrawal and conditions of powerlessness" (see introduction, this issue), then this Venezuelan sociality is thoroughly 'theopolitical'. As I discuss below, rather than spiritless, this sociality is an intensely metamorphic milieu imbued with myriad globalized spirits that always act on the brink of withdrawal. Not only that, far from once and for all settling on any one of these two poles, these theopolitical apparitions constantly waver between 'presence' and 'absence', the 'visible' and the 'invisible', in a play of 'hide' and 'seek' that frustrates the Bolivarian state's intrinsically politico-theological project of pinning things down so as to subject them as fully present entities to its totalizing ambitions. We are far removed here from the monotheistic Spirit of political theology that acts as a willful sovereign agency, dominating a world bereft of any spirit of its own.

The second point I wish to make is that when confronted by an excessive, theopolitically imbued sociality that does not readily lend itself to any hegemonic, politico-theological design for encompassing this sociality as a clearly bounded 'people', the Chavista project mutates. ${ }^{8}$ Over time, and regardless of all the grandiose proclamations to the contrary, Chavismo sets aside any and all hegemonic pretensions, and, still bent on retaining its hold over an ever-elusive, fugitive sociality, increasingly privileges the moment of sheer force and domination over and against these ambitions. As the politico-theological 'retreats' and is theopolitically retraced, the political logic that best 
characterizes Chavismo, along with other so-called populist movements that operate today under neoliberal conditions, is not hegemony, then, but, in Ranajit Guha's (1997) illuminating formulation, 'dominance without hegemony', that is, a situation in which, similar to what Guha describes for colonial India, the relations between the Chavista state and ever-larger sectors of the population are defined not by hegemonic consensus but by sheer coercion with democracy at best reduced to the role of sugarcoating more unpalatable realities. ${ }^{9}$ Within this political logic, 'the people' is not any democratically constituted entity but whatever those in power 'lovingly' designate as such from above, often in violation of any of the established democratic procedures.

\section{Theopolitics and the 'Retreat' of the Politico-Theological}

Of all the elements that contribute to the current neoliberal predicament that the Chavez regime inherited, from rising inequality to widespread privatization, it is the breakdown of political representation that in the end has had the largest impact on Chavismo. This breakdown in institutional legitimacy is rooted in the late 1980s and an IMF program of structural adjustment implemented between 1989 and 1993 that, among other things, resulted in the withdrawal of subsidies of "a broad range of public services and consumer goods" (Roberts 2003: 63), with all that this entailed, including a loss of public confidence in the institutions of the state (see also Lander 1996). Rather than any supposed top-down 'democratic' control of the majorities, it is this nearly complete loss of legitimacy of all representative institutions amid a catastrophic retreat of the theologico-political or of the state's ability to hegemonically encompass sociality as a totality that is the key dimension that must be taken into account when it comes to apprehending the meaning, logic, and dynamism of Chavismo as a populist movement. ${ }^{10}$

On the basis of fieldwork carried out in diverse parts of Venezuela during the 1990s and 2000s, I identified two crucial effects of this momentous breakdown. One is the unveiling of a crowd sociality that has always been there, not only in Venezuela but everywhere else as the more or less unacknowledged, primordial ground upon which social institutions and modes of social organization precariously rest. If, in line with Lacoue-Labarthe, Nancy, and others, I refer to this crowd sociality as primordial, this is because it is always already there as the multiple, emotionally laden, densely articulated togetherness or 'being-with' (Nancy 2000) that, even before birth, precedes everyone from the start, and from which everyone receives, largely through emotionally laden processes of mimetic contagion, the very changing sense of who they are (Borch-Jacobsen 1988: 127-244; Lacoue-Labarthe and Nancy 1997). Composed of myriad images, emotions, gestures, forms of behavior, styles of apparel, or ideas ceaselessly 
circulating among people as they 'touch' each other, this crowd sociality is, in turn, the excessive, often disavowed ground that, ultimately unsuccessfully, social institutions always strive to both shape and contain. ${ }^{11}$

It is precisely this excessive crowd sociality that erupted in Venezuela in broad daylight in the 1990s, largely as a result of the nearly complete collapse of the nation's system of political representation induced by the previously mentioned IMF-imposed austerity program of structural adjustment. No longer contained, no matter how precariously, by the nation's representative institutions, now afflicted by an incurable loss of legitimacy, and coming together in possession cults, Pentecostal churches, informal markets, mass demonstration, and the like, this tumultuous, relatively formless crowd sociality became the site of emergence of a prodigiously mobile, mimetic, and metamorphic popular subject, often capable of eluding the forms of classification and the interpellations with which the state seeks to apprehend it. Incited by manifold consumer images and desires, this popular subject is capable of adopting a prodigious superabundance of identities and roles, each more or less suited to the solicitations of the ever-differentiating contexts that s/he meets, while horizontally traversing the national territory in search of livelihood, affiliation, and identification. ${ }^{12}$

I first became aware of Venezuela's highly mobile, mimetic popular subject a few years ago while doing fieldwork on the María Lionza cult. Centered around Queen María Lionza, a Spirit Queen whose legendary origins putatively hark back to pre-colonial times, the cult of María Lionza is a possession cult with manifold adherents all over Venezuela, and particularly in the more populous neighborhoods of the big cities. Organized around domestic altars erected in the private dwellings of the cultists, the cult gravitates around the main pilgrimage centers of Sorte, Quiballo, and Aguas Blancas, located in adjacent mountains in the western Venezuelan state of Yaracuy.

Amounting to a gigantic open-air theater of spirit possession, one of these sacred mountains was the site of my initial encounter with the kind of crowd sociality to which I have been alluding, with a multitude of María Lionza followers stretched out in close proximity to one another across the mountain's ascending green slopes. It is in these fabulous surroundings, under the green canopies of very tall trees and in the presence of their followers and clients, that the cult mediums become possessed in serial succession by myriads of 'vernacular' and 'globalized' spirits, such as Venezuela's Founding Fathers (foremost among them Bolívar), Wild Indians, Vikings, Barbarians, Egyptian Pharaohs, and stars from the Golden Age of Mexican cinema.

Within this scene, any politico-theological pretension of Spirit to bring back or represent to itself the 'visible' empirical manifold as this manifold's 'invisible' totalizing principle or foundation is continuously overridden, deconstructed even, by a myriad of globalized spirits. Any attempt on the part of putatively invisible Spirit to render this manifold fully present and visible so as to make it 
available to its sovereign dictates is frustrated by these spirits' ceaseless coming and goings. Indeed, in and of itself, these migrant spirits' appearances and disappearances suffice to make any sovereign go mad. Serially taking over the bodies of the mediums only to then pass away to make room for the next, the María Lionza spirits' comings and goings trouble any stable distinction or demarcation between the 'seen' and the 'unseen' or the 'material' and the 'spiritual' on which any political theology is contingent. As suggested earlier, the movement whereby the María Lionza spirits take possession of the mediums' bodies only to then go away without claiming any foundational stability for themselves, acting instead through withdrawal and powerlessness, is distinctively theopolitical. Even if Bolívar, the Founding Father of the Venezuelan nation, is one of the spirits of 'highest light' (de más alta luz) in the María Lionza possession cult, for the most part the cultists resolutely leave behind any archaeological appeal to fatherly foundations as they become possessed in serial succession by myriads of globalized, ever proliferating spirits.

Faced with this scene of possession by the 'local' and the 'global'-heroic spirits of the Venezuelan War of Independence, alongside spirits drawn from syndicated television-I eventually realized that the cultists were venturing into an ever-expanding globalized landscape beyond the reach of the nationstate. Driven beyond the borders of the nation-state by the multitudinous alterity by which they are possessed, the cultists were joining through possession a virtual, truly borderless realm traversed by myriad globalized images-a realm that permanently threatens to deconstruct the state imaginary of the nation (Sánchez 2001). ${ }^{13}$

Later fieldwork among Pentecostal squatters who had illegally seized and occupied empty buildings in the city of Caracas-often through violent criminal means-further consolidated my initial impression of a popular Venezuelan subject for whom affective mimetic contagion, ceaseless mutability, and incessant deterritorialization amount to a veritable existential condition (Sánchez 2008). There are significant differences between the María Lionza cultists and the Pentecostal squatters. On the one hand, there is the media-driven penchant for dissemination of the María Lionza cultists, according to which the mediums of the cult see themselves serially possessed by an endless gallery of characters and roles. On the other hand, there is the insistence with which the Pentecostal squatters decipher the will of the Holy Spirit scripted on their emotionally ravaged anatomies as they violently seek to reclaim for the One a world that, precisely on account of its relentless dispersion and dissemination, they unequivocally identify as fallen. As suggested by the Pentecostal squatters' willingness to bring down their enemies in a hail of bullets, in this process the Holy Spirit loses much of its holiness, turning for all practical purposes into a rogue operator, an insatiably hungry ghost criminally bent on swallowing ever-larger swaths of urban real estate for itself. Nevertheless, beyond 
their differences, both cultists and squatters disregard any strict demarcation between the 'seen' and the 'unseen', making ample use of their affective and affected, uncontrollably crying, gesturally excessive, emotionally altered anatomies as the malleable medium where the traces of the invisible, withdrawing Other are momentarily rendered visible, inscribed, modified, and passed on in a process of continuous, relentless reinvention. For both cultists and squatters, what is at stake in their ecstatic practices is the achievement of both material and spiritual ends by possessed subjects that, for this very reason, and even if in the name of the Other, are in their very dispossession, vulnerability, and powerlessness nonetheless theopolitically able to act. Considering how much their agentive power is contingent on their radical lack of agency and powerlessness, to speak of theopolitics in reference to the spirituality of the María Lionza cultists and the Pentecostal squatters is clearly warranted. Indeed, unlike Simón Bolívar, the invisible Sovereign Spirit presiding over the Chavista politico-theological universe, both cultists and squatters lack any agency and power that they may properly call their own. As possessed subjects they, instead, are the mere bodily vehicles of numinous forces that, in what amounts to a kind of powerlessness, always act on the brink of withdrawal.

Something similar may be said about the hunger strikes and the public displays of self-crucifixion that in recent years have become so generalized in Venezuela. Evoking Christ at its point of maximum powerlessness and withdrawal, mimetic expressions such as these allow subjects to make use of their own corporality in all of its vulnerability and affective ductility as the preeminent instrument of resistance to the most varied forms of state power (Vásquez Lezama 2016; see also Vásquez Lezama 2014). In other words, the most heterogeneous empirical evidence clearly suggests that this spiritually haunted, excessive corporality is today, in all of its affectivity and metamorphic malleability, the theopolitical nexus where popular subjectivity in Venezuela spectacularly plays out its most crucial stakes. Among these are the struggle for housing in circumstances where the majority of the population does not have access to it, as in the case of the Pentecostal squatters, and the way in which the followers of María Lionza expose their bodies to the numinous in order to enlist it in their efforts to gain access to jobs, health, or a lover. Last but not least are those bodily performances where what is at stake is the resistance, through corporality, to the pretensions of the state to block its subjects' access to the means for reproducing their lives, as is the case of the agriculturalist Franklin Brito analyzed by Vásquez Lezama (2016). ${ }^{14}$

That what amounts to a "mattering-forth of the collective flesh" (Mazzarella 2019: 45) - the subjects' corporality in all of its sensuous capabilities, passionate disposition, exposed vulnerability, and plasticity-has assumed a central place as the mediating matrix of all the most significant social and political processes, in retrospect, almost goes without saying. The growing pre-eminence and power 
of this matrix are what one would expect when the representative institutions of the state lose their capacity to mediate the interests and identities of individuals. In circumstances when the powerful machinery of sublimation that is political representation no longer fulfills its mediating functions, as in Venezuela after the IMF-imposed austerity program, the corporality of individuals comes to the fore as the malleable, sentient medium through which social processes are mediated, endured, mimetically experimented upon, and endowed with meaning.

This, at least, is what has happened in Venezuela. The public spaces left vacant by the state in its incapacity to represent society have become filled by masses of individuals from the most diverse walks of life, coming together in spirit possession cults, Pentecostal churches, informal markets, and other at best loosely institutionalized settings bent on instantly representing themselves. Exposed like the María Lionza cultists or the Pentecostal squatters in all of their sensuous, sentient corporality to one another across horizontal space as members of crowds, their bodies often pressing against each other, these individuals, rather than passively acquiescing to being represented by others, instead insist on presumably unmediated presence (of spirits, their interests, desires, etc.) as the foremost, paramount value. All of this, I propose, amounts to a preeminence of the theopolitical horizontal over the politico-theological vertical as the axis along which forms of personal and social experience and relations are formed, unformed, and transformed. Horizontally exposed to each other across real and virtual space and largely beyond the reach of any controlling institution, people in this crowd-like situation are free to mimetically borrow from one another, competitively adopting each other's identities, roles, appearances, styles of address, emotional predispositions, bodily demeanors, desires, yearnings, and so on.

Along with the popular Venezuelan subjects' metamorphic wanderings and heterogeneity, the other effect of the breakdown of Venezuela's system of political representation is the growing inability, under such circumstances, of political agents to extricate themselves from the particularities in which they are immersed and, occupying the place of the universal, to plausibly represent sociality both to others and to themselves as $a$ common 'people', where the majority of the population may enduringly recognize itself. Under the highly deinstitutionalized circumstances in which Venezuelans found themselves in the early 1990s after the imposition of the IMF's program of structural adjustment, it is not representation but, as among the María Lionza cultists and the Pentecostal squatters, bodily affective contagion-the mimetic borrowing and emulation among subjects horizontally extended across continuously expanding real and virtual space, relatively freed from the "stings of command" of which Elias Canetti (1962: 316) so eloquently spoke-that sets the tone.

The peculiarities of the kind of revolutionary populism that Chavismo instantiates largely issue from the fact that it emerged in response to, and had to deal 
with, such a volatile state of affairs, one in which the breakdown of political representation corresponded to the emergence of a prodigiously mobile and mimetic popular subject resilient to the state's totalizing ambitions. It is within this slippery terrain, in all of its theopolitical complexity and heterogeneity resilient to populist seizure, that Chavismo had to operate from the beginning. If what is at stake is apprehending the nature, inclinations, and modus operandi of Chavismo as an anti-neoliberal political phenomenon emergent in times of neoliberal globalization, fear of democracy, which so troubles analysts like Zakaria, is the misplaced sentiment. Rather than asking whether this political movement privileges democratic 'equality' to the detriment of 'freedom', as analysts like Zakaria often do, grasping the inherent significance of Chavismo as a political regime demands adopting an altogether different point of view for which the question of democracy is, at best, secondary. Once again, to achieve such an understanding one must assume as the analytical point of departure the juxtaposition between, on the one hand, the hubristically totalizing, politicotheological ambitions of Chavismo as a properly revolutionary political movement relying on democracy only insofar as it is expedient to do so, and, on the other, the fractured, ever-differentiating crowd conditions with which such ambitions had to come to terms from the start.

Nowhere were the traces of this crowd environment more visible than in the political rhetoric, style of rule, and overall bodily demeanor of Chávez himself who, in his public allocutions, used to seamlessly switch registers from the sublime to the most mundane and banal. "Aló Presidente" (Hello President), the radio and television program that Chávez conducted every Sunday before audiences made up of common people, foreign visitors, national and international journalists, and members of the government, is a good example of the almost vertiginous change of registers that characterized his political style. On those occasions, Chávez switched without warning from speechifying in the purest heroic style, composed of sublime phrases destined to be cast in bronze or stone, to giving advice about the adequate use of water or electricity, singing Mexican country music or Venezuelan joropos (folk songs), and one time even offering a detailed narration of his misadventures with his digestive tract. So much mutability and nervous change of registers from the sublime to the banal and back cannot, I believe, be understood without taking into account the ruler's compulsion to affectively seize and bodily represent the inherently distracted, intensely mobile, mutable, mimetically unstable, ever-elusive masses to which he addressed himself. With the political style and bodily demeanor of the ruler as a palimpsest where the traces of the crowds may be discerned, one mutability, in sum, was the faithful register of the other.

Similar to what may be said in the US about Trump's anxious tweeting behavior, all of this suggests that instead of collecting the crowds around himself, of being chased by these crowds as their undivided focus of narcissistic 
love (for the One), attention, and identification, Chávez was, one might say, much like other 'new' populist leaders around the world today, forever chasing the nation's crowds. ${ }^{15} \mathrm{He}$ was, in other words, positioned by these crowds' theopolitics and their economically and media-induced mobility and distraction in a desiring relationship vis-à-vis them as an ever-expanding, continuously differentiating field of relentless dispersion. This means that the nation's crowds were not just ahead of him; they were also always taking off from Chávez, pulled away from him in myriad directions by the wildly heterogeneous images (along with their attendant longings and aspirations) that, all the way from Vikings and Barbarians to glittering consumer goods and Mexican movie stars, continuously reach the Venezuelan population via the globalized media. The critical purpose of Chávez's anxious chase of the crowds was thus none other than provisionally constituting or carving a somewhat governable 'people' out of this crowd-a field of ineradicable dispersion from one object of desire or experience to the next that ultimately eluded the ruler's grasp. Populist leaders, in other words, are not what they used to be.

Confronted with the slippery terrain brought about during the 1990s by globalization, the Chavista state was from the start politico-theologically incapable of totalizing sociality as $a$ 'people' answerable to its interpellations and dictates. Chávez used to insist on the necessity of putting the political in command, thus unambiguously expressing his hubristically totalizing ambitions. Yet at the time it was voiced, this totalizing insistence was already extemporaneous. If the 'political' is the transcendental politico-theological capacity to totalize society, then, not only in Venezuela but everywhere else, it is not 'the political' but the retreat of 'the political-theological' (cf. Lacoue-Labarthe and Nancy 1997) that is pervasive today.

\section{Chávez's Eyes}

In every political regime, for totalization to happen and sociality to crystallize as $a$ society, this heterogeneous and, in principle, borderless sociality must collect itself around and mimetically identify with a figure, be it a leader, a principle, a Founding Father, or a symbol-that which is the most emblematic expression and manifestation of the whole, its most faithful reflection (LacoueLabarthe 1990: 77-99). It is only through mimetic identification with a totalizing figure that a heterogeneous mass can crystallize, if only momentarily, as a homogeneous and unified 'people' capable of answering to the interpellations, dictates, and demands of the state. ${ }^{16}$ Therefore, the retreat of the political-theological is also the retreat or the retraction of the totalizing figure. Itself a hybrid of neo-classicism and romanticism, the figure of Simón Bolívar, supreme hero of the wars of independence against Spain and founder, among other nations, 
of modern Venezuela, has long been the indisputable emblematic figure of the Venezuelan people/nation. The effigy of the Liberator is everywhere: stamped on walls, bridges and buildings, as well as on the national currency, and represented in the portraits, busts, and equestrian statues that so often occupy the central square of Venezuelan towns and cities.

While the retreat of the political-theological-and, with it, the ability of the state to hegemonically encompass and represent sociality-has afflicted Venezuelan republicanism from the beginning of the republic, within the current, intensely globalizing circumstances this 'retreat' has intensified drastically. Perhaps the most flagrant expression of such a retreat, as itself a retreat of the figure of the totality, are the billboards depicting the 'eyes of Chávez', which the regime disseminated all over Venezuela in the wake of the ruler's untimely death (fig. 1). These billboarded eyes are a citation of the eyes of Simón Bolívar, extricated from the hero's canonical nineteenth-century portraits so as to suggest the hero's all-seeing gaze over the nation. ${ }^{17}$ This should come as no surprise, given how extensively the political theology of the Chavista regime-of the 'Bolivarian Revolution' as it often calls itself-has sought to present Hugo Chávez as a stand-in or substitute for the Founding Father. Evoking a supernatural apparition that, tacitly, conjures the Spirit of Bolívar as the animating Spirit of the Venezuelan nation, the eyes of Chávez are strangely represented, abstracted from the

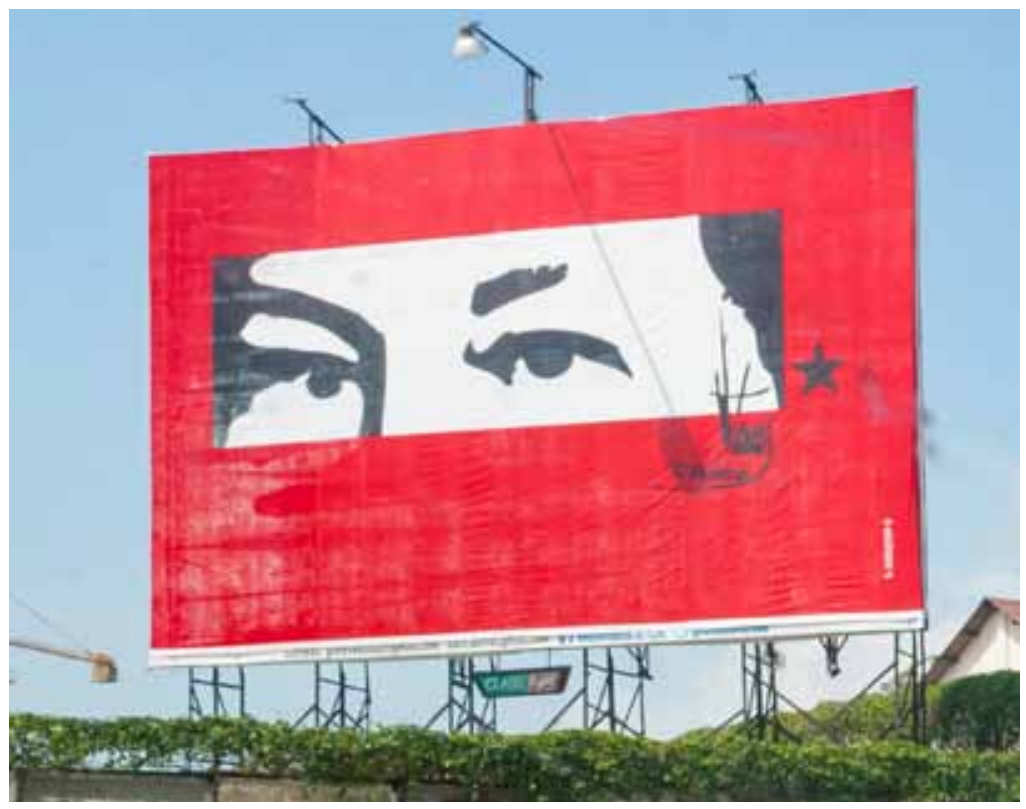

FigurE 1: The eyes of Chávez. Bolivarian propaganda in Guarenas.jpg ${ }^{\odot}$ Wilfredor/ Wikipedia, CC0 1.0 Universal Public Domain Dedication, Wikimedia Commons 
ruler's body and framed within a rectangle enclosed by another rectangle with the latter's signature often stamped below the representation.

Even if it is indeed the case that sovereignty is always already a phantasma thoroughly aporetic entity that, as Michael Naas (2015: 58) has argued, following Derrida, issues from a confusion between "what must be and what is," between a performative "as if" and a constative "like that" (comme ci, comme ça) - in the case of the 'eyes of Chávez', the phantasmatic character of sovereignty is starkly exposed. While the regime's intention in disseminating this image was to performatively pull off a trick, making it seem as if Chávez continued ruling Venezuela after his death, the truth nevertheless is that this representation lacks all verisimilitude, or like that-ness.

Instead of the billboarded eyes of the dead ruler appearing 'as if' they are 'like that' - that is to say, a sign of his continued sovereignty - what the eyes of Chávez suggest, in all of their uncanniness, is the complete irrelevance of the dead ruler with regard to the affairs of this world. The eyes of Chávez simulate the living only to make clear that, having withdrawn from the world, they are no longer of the world or relevant to it. Ultimately, what these disembodied eyes intimate is that the politico-theological figure in the Venezuelan carpet ${ }^{18}-$ the palimpsest of Chavez-Bolívar-is rapidly fading, leaving in its place an uncertain weave full of holes, lacerations, and discontinuities.

\section{Dominance without Hegemony: Populism as a War Machine}

Regardless of all claims to the contrary, Chavismo's hegemonic project of subjecting such an uncertain, intrinsically non-totalizable social field to its own political theology necessarily misfires. Indeed, as a possibility, hegemony was never really in the picture. The social and political scene under Chavismo has always been way too volatile and unstable for one to be able to speak of a successful hegemonic consolidation in the sense of the imposition through culturally persuasive means of the worldview of a ruling class or dominant group on heterogeneous social sectors. Also unlikely is that those sectors would thereby come to accept such a worldview as the common-sense expression of how things really are, of the true order of things in a whole society from which all of these sectors benefit and in which all of them have a stake (Gramsci 2011: 233-238). ${ }^{19}$

Instead, something else comes about as a result of the massive quantities of sheer force that the regime must apply to the doomed hegemonic project of totalizing a social field that, by its very nature, is intrinsically non-totalizable. As intimated earlier, faced from the start with a momentous retreat of the political-theological, the largely unintentional outcome of Chavismo's ultimately failed hegemonic, politico-theological project of totalizing society in a revolutionary direction is not hegemony but 'dominance without hegemony'. That is, 
much as what Guha (1997) analyzed for colonial India, a situation in which, setting aside any attempt at hegemonic encompassment, the Chavista state and an ever-shrinking group of supporters collecting as a tribalized partiality around this state relate to the rest of the social field in terms not of hegemony but of sheer, crude domination. Through it, Chavismo only precariously succeeds in forcefully controlling an always retreating, ever-differentiating social field riven by myriad conflicts unexpectedly erupting in the most unexpected spots without, for that matter, ever really managing to carve out of this field an enduring, comprehensively homogeneous 'people', a totality beholden to the figure of Bolívar, and, through it, to the Bolivarian state. Another way of saying this is that the regime's 'collecting' and centrifugally people-making forces are continuously beset by a host of 'dispersing' or 'disseminating' centripetal forces that continuously derail them. ${ }^{20}$

To gain a better sense of how this all comes about, it suffices to return briefly to the María Lionza possession cult. Insofar as it starkly reveals its highly deinstitutionalized, intensely mediatized, emotionally laden, and mimetically driven nature, rather than exceptional, this cult is just one singularly emblematic instance of the crowd sociality that rose to center stage all over Venezuela in the wake of the vast crisis of political representation that shook this nation in the 1980s and 1990s. Imbued with myriads of globalized spirits-once again, Wild Indians, Vikings, Barbarians, Mexican movie stars, Egyptian Pharaohs, and so on-forever serially taking off from Spirit or from the One as incarnated in the cult by the spirits of Bolívar or María Lionza as avatars of the nation-state, ${ }^{21}$ this runaway sociality confronts the state's political theology and its monotheistic drive to yoke all this wild polytheistic proliferation to itself with a deconstructive theopolitics of its own. Instead of any clear-cut politico-theological partition between the 'visible' and the 'invisible' aimed at rendering sociality into a fully present, reified entity, what the María Lionza cult intimates is something altogether less certain-namely, a theopolitical predicament in which, through possession, the boundary between the two trembles. Here is a haunted terrain where no identity is ever fixed as all continuously transform along a serially expanding metonymic chain forever eluding the identifying grasp intrinsic to any politico-theological, all-encompassing, spiritually totalizing principle.

This runaway crowd sociality cannot be totalized. In the face of such an impasse, to insist on trying to hegemonically shape intrinsically non-malleable material into a governable 'people' is to subject sociality to indiscriminate violence, both physical and symbolic. The reason for this is relatively straightforward. From all that has been said, it should be clear that, in line with the regime's Bolivarian political theology, any effort to instantiate Chavismo's seamlessly homogeneous, governable 'people' beholden to the Bolívar state presupposes wresting 'this people' away from an ever-withdrawing 'popular' terrain, that is, the crowds, which, as in the María Lionza cult, forever move 
away from any putative origin or foundation. Indeed, as the cult's mediums mimetically adopt in succession an ever-proliferating cast of globalized spirits, they distractedly leave behind Spirits such as those of Bolívar and María Lionza, which in the cult are emblematic of the Venezuelan nation-state. Given, then, the intensely generative and disseminating character of Venezuela's crowd sociality, theopolitically imbued as it is by myriad globalized spirits along with a welter of consumer images, desires, and expectations, it should be clear that only the most devastating collecting powers of the state can possibly be up to the task of constituting a minimally governable people, no matter how precariously or for how long. Collection, in other words, must be set in agonistic tension with dispersion or dissemination if something like a governable Chavista 'people' is to ever come out of the crowds' malleable milieu. This violence does not follow the sacrificial rhythms of any political theology once and again sublimating the world for Spirit. Instead, similar to what happens with the Holy Spirit of the Pentecostal squatters, in the current, intensely globalized conditions, Bolívar, the exalted Spirit of the Bolivarian politico-theological universe, sheds any totalizing pretensions and turns into a rogue operator. Any initiatives undertaken in His name and on His behalf are geared toward violently putting out the fires that keep sprouting everywhere in the most unexpected points of the social landscape.

A 'people' so agonistically contrived out of an ever-disseminating social field is a necessarily fragile, precarious assemblage, held together by the state in tension with a host of deconstructive centripetal forces that continuously chip away at its existence. Such a precarious 'people' is not and cannot be a hegemonic, politico-theological construct, if by this one understands an entity with which, beyond their differences, a majority of the population identifies as the incarnation of the collectivity. Much as happens with Trump's true 'American people', depleted as it is by the centripetal forces of a theopolitically imbued sociality, increasingly the Chavista people is an ever-shrinking part of the population, continuously locked in protracted conflict with the rest. ${ }^{22}$ It is in the name of this shrinking 'people' as the putative, somewhat phantasmatic subject of the neoliberal processes to which the Chavista state is subordinated that this state 'democratically' rules. This is all to say that in what amounts to a Humpty Dumpty effect ("a word ... means just what I choose it to mean"), rather than any grandiose, seemingly cohesive whole, in present-day revolutionary populism (Chavismo included), what 'the 'people' really means is " $m y$ people," that is, a wholly tribalized conglomerate.

Populism has been called by Laclau (2005: 67) the "royal road" to the political, the means whereby, through reiterated appeals to a homogeneous 'people', a political order torn apart by intractable antagonisms is made whole again. When, as nowadays in Venezuela, 'the political' is horizontally beset by the centripetal forces of an ever-differentiating sociality and the very possibility of 
durably installing a totality is in question, populist interpellations acquire new, non-totalizing ideological functions. In other words, under such circumstances these interpellations increasingly operate according not to a totalizing but to a thoroughly 'tribal' logic. Their addressee is not any whole 'people' encompassing the majority of the population but, unabashedly so, only a 'part' of it presumably bent on dominating the rest-hence my use of the word 'tribe'. Not hegemony, then, but 'dominance without hegemony' is the political logic that, beyond any grandiose ideological claims, effectively characterizes Chavismo as a populist movement aimed at dominating the political field and not in any way totalizing it. ${ }^{23}$ The Chavista pretension to totalize what, by its very nature, is non-totalizable renders sociality into a battlefield with no resolution in sight.

No such dominating logic can possibly be implemented if a war machine understood as an ensemble of practices orchestrated by the state aimed at either neutralizing or annihilating any real or potential enemies is not set up precisely for this purpose. What, then, are some of the main elements composing the war machine that the Chavista regime has erected over time? Here are some of the more prominent: gerrymandering; insistently undermining every trace of a functioning division of powers; the insistent recasting of opponents as enemies; a highly discriminating distribution of resources such as food and health supplies among the popular sectors in order to reward followers and chastise the insufficiently aligned; the insertion of Cuban intelligence deep within the armed forces, a move that, so far, has been quite effective in suffocating any coup attempt by the military before it has any chance to develop; the creation of a parallel state with assistance from Cuban volunteers in order to selectively attend to the needs of the population in domains as varied as health, education, or housing; a Manichaean emotional economy that reserves 'love' for the followers and sheer hatred and criminalization for the enemies as the anti-people; the ever more widespread practice of summary executions carried out by the state and allied paramilitary groups in the popular neighborhoods of Venezuela's main cities; the constant arbitrary change of the rules of the game; the systematic denial of resources to the opposition; the persecution of political opponents to the point of subjecting them to various forms of torture and disappearance (Cumming-Bruce 2020). The list goes on.

The fragmented social terrain within which Chavismo operates and strives to dominate is also what keeps the regime's populist war machine going, even if this comes at the cost of rendering sociality ever more unpredictable and chaotic. ${ }^{24}$ Indeed, the extraordinary investment of state forces needed to try to realize an ultimately unrealizable hegemonic project can only leave wreckage in its wake: the ruined civic spaces and institutions of a thoroughly devastated sociality. Under the current intensely globalized conditions, such a project is a sure recipe for turning the chaos already afflicting sociality into a thoroughly endemic condition. 


\section{Acknowledgments}

I have benefited from the comments and insights of audiences in conferences at Cambridge University (CRASSH, 2017), the University of São Paulo (2017, New Delhi (ICAS-MP, 2018), Mexico City (CIDES/Columbia University, 2018), and UCL Anthropology (2018), as well as from a talk given at Princeton University's PLAS (2018), when I was a Visiting Research Scholar. I especially would like to thank Tanya Filer, Joao Felipe Gonçalves, Javier Guerrero, Martin Holbraad, Myriam Lamrani, Claudio Lomnitz, Prabhu Mohapatra, Gabriela Nouzeilles, Bjørn Thomassen, and Ravi Vasudevan for their illuminating comments and suggestions as well as for their gracious hospitality. Benjamin Arditi and JeanLuc Nancy generously commented on earlier written versions of this article, for which I am greatly appreciative. An earlier, considerably shorter version of this article was published with the title "Post-Truth Populism in Venezuela" in Global Challenges, September 2020.

Rafael Sánchez is a Senior Lecturer at the Graduate Institute of International and Development Studies in Geneva. He was a Visiting Research Scholar and Lecturer at Princeton University's Program in Latin American Studies (PLAS) in 2018 and a Visiting Scholar at NYU Shanghai in 2017. His publications include articles on media, mass politics, populism, and spirit mediumship and his book Dancing Jacobins: A Venezuelan Genealogy of Latin American Populism (2016). He is currently researching a project focused on contemporary urban Venezuela, "The Fate of Sovereignty in the Landscape of the City," and is investigating the lives of Venezuelans migrants in the borderlands between Venezuela and Colombia. E-mail: rafael.sanchez@graduateinstitute.ch

\section{Notes}

1. Unless otherwise indicated, all translations are my own.

2. According to most surveys previous to the elections, the vast majority of the population neither backed the president nor was in favor of the government's proposition.

3. Although this article focuses on Chavismo, I consider much of what I say to be relevant to other post-truth populisms of both the right and the left that, in recent years, have been emergent throughout the world, including Trumpism in the US and Putin in Russia. Unfortunately, reasons of space do not allow me to develop in any detail this aspect of the argument. 
4. I owe this succinct formulation to Justin Sully (pers. comm., 20 August 2020).

5. I hasten to add that in speaking of 'post-truth' I do not mean to imply, as some do, that there was a time when accounts of any given state of affairs were indisputably truthful and factual. What I have in mind here is something quite different, namely, that in our post-hegemonic times the conditions are no longer present for instituting one version of reality as the truth while temporarily suppressing all the alternative versions as false.

6. Throughout the article, I use the capitalized singular 'Spirit' to refer to the hierarchically superordinate, all-encompassing, totalizing entities of political theology. The word 'spirits', on the other hand, alludes to the non-hierarchized plurality of undecidedly spiritual cum material entities that make up the theopolitical.

7. For this division into two parts as the quintessential operation of the politicotheological machine, see Esposito (2015).

8. Although not addressed in this article, in order to get a better sense of the challenge that a hegemonic project like Chavismo nowadays confronts, one would minimally have to add to this excessive sociality the wide range of cultural, financial, and economic flows that lie beyond the Venezuelan nation-state's ability to control, manage, and totalize.

9. Trump's recent call to "dominate the streets" in response to the Black Lives Matters protests clearly suggests that this privileging of the moment of force over any more hegemonic pretensions is not exclusive to Chavismo but characterizes other contemporary populisms of both the left and the right all over the world (Reuters Staff 2020).

10. I should point out that, regardless of Chavismo's flaunted anti-neoliberalism, ever since this political movement came to power the insertion of Venezuela into the neoliberal international order has only deepened, an insertion predicated on the socially exploitative and ecologically destructive logic of mineral extraction promoted by the regime. For more on this logic, see Rosales (2017).

11. For the notion of the 'touch' and its centrality to crowd processes, see Canetti (1962).

12. When I allude to the Venezuelan popular subject's poverty, what I have in mind is no mere material deprivation, although that too, but, more metaphysically, the poverty of being to which Diderot refers in his 'paradox of the actor', on account of which, precisely because s/he is 'nothing', the actor can become everything. In this respect, see Lacoue-Labarthe's (1989) brilliant "Diderot: Paradox and Mimesis."

13. Due to limitations of space, I cannot address here the reasons why the globalized spirits of the María Lionza cult are so threatening to Venezuela's state imaginary. Suffice it to say that this is an imaginary centered around the monumentalized figure of Simón Bolívar, Venezuela's Founding Father, surrounded by other equally monumentalized, presumably exclusively autochthonous figures (indigenous caciques or chieftains, heroes from the Venezuelan War of Independence against Spain, and so on), and this makes precious little room for any symbolic expression of foreignness. For a sustained exploration of this imaginary and how it historically came about, see Sánchez (2016). 
14. See Guerrero (2012: 17-38) for a fascinating exploration of the role of the body within collective representations as the "privileged site where Venezuelan politics is contested." See also Duno-Gottberg (2009).

15. It is nevertheless worth mentioning that already in the nineteenth century none other than Gustav Le Bon "reported the story of a man chasing after a crowd of protestors saying he had to catch them because he was the leader" (cited in Hollander 2009: 151). This story suggests how much in Le Bon's times crowds already possessed a momentum of their own that, contrary to what this author often claimed, was not subordinated to any leader figure.

16. This section draws on the epilogue of my book Dancing Jacobins: A Venezuelan Genealogy of Latin American Populism (Sánchez 2016).

17. I especially have in mind here a T-shirt that I bought some years ago in Caracas, long before Chavismo came to power, where a series of rectangularly framed Bolívar eyes from the hero's nineteenth-century portraits appear stacked on top of each other. The caption "The gazes of Bolívar," inscribed under the series of stacked eyes, completes the composition.

18. The reference here is to Henry James's novella The Figure in the Carpet where the narrator obsesses with discovering the meaning or 'figure' behind his favorite author's works.

19. The insistence with which, from very early on, the rhetoric of Chavismo opposed the Chavista 'people' to a 'civil society', presumably encompassing Venezuela's relatively vast middle classes, strongly suggests that, despite proclamations to the contrary, Chavismo gave up any hegemonic pretensions almost right from the beginning, and, as it became exposed to the highly resilient social predicament within which it had to operate, increasingly gave in to the kind of 'dominance without hegemony' that I address in this article. See in this respect Chávez (2000).

20. On 'collection' and 'dispersion' as opposed tendencies at work with singular intensity within the populist social field, see Sánchez $(2001,2016)$. See also Mazzarella (2019), who, if I understand him well, uses the terms 'coagulation' and 'solvent' to reference broadly overlapping even if not altogether identical processes.

21. On the fetishization of the Venezuelan state through figures such as Bolívar and María Lionza, see Taussig (1997).

22. This sociality is nowadays dramatically instantiated by the spectacle of countless Venezuelans, the so-called walkers, who are escaping the devastating effects of a catastrophic economic situation by, literally, walking away from the nation into neighboring countries in what amounts to an interminable procession. In a current project, I am exploring this phenomenon in its socio-religious dimensions.

23. That an expression Guha used to characterize the nature of British colonial rule in India seems eminently applicable not only to Venezuela's Chavismo but also to other contemporary populisms in the US, Europe, and elsewhere suggests how much political life nowadays is witnessing a return of the colonial relation to the very center of sociality from the peripheries to which it was supposedly confined. 
24. Even if in the case of Chavismo such a terrain is singularly intractable, I would argue that any so-called new populism operates in a social landscape that does not lend itself to be hegemonically mastered.

\section{References}

Borch-Jacobsen, Mikkel. 1988. The Freudian Subject. Trans. Catherine Porter. Stanford, CA: Stanford University Press.

Canetti, Elias. 1962. Crowds and Power. Trans. Carol Stewart. New York: Farrar, Straus and Giroux.

Chávez, Hugo. 2000. “Aló Presidente $N^{\circ}$ 40” [Hello President No. 40]. http:// www.todochavezenlaweb.gob.ve/todochavez/3813-alo-presidente-n-40.

Cumming-Bruce, Nick. 2020. "Venezuelan Leaders Implicated in Crimes against Humanity by U.N. Investigators.” New York Times, 16 September. https://www. nytimes.com/2020/09/16/world/americas/venezuela-un-killings-torture.html.

Duno-Gottberg, Luis. 2009. “Narrativas Somáticas y Cambio Social: Notas para el Cuadro Venezolano" [Somatic narratives and social change: Notes relevant to the Venezuelan framework]. Estudios 17 (34): 403-437.

Esposito, Roberto. 2015. Two: The Machine of Political Theology and the Place of Thought. Trans. Zakiya Hanafi. New York: Fordham University Press.

Gramsci, Antonio. 2011. Prison Notebooks. Ed. and trans. Joseph A. Buttigieg with Antonio Callari. New York: Columbia University Press.

Guerrero, Javier. 2012. “Culturas del cuerpo: La 'sagrada’ familia venezolana” [Cultures of the body: The 'sacred' Venezuelan family]. $452^{\circ} \mathrm{F}$ : Revista electrónica de teoría de la literatura y literatura comparada 6: 17-38. https://revistes.ub.edu/index.php/452f/article/view/10825.

Guha, Ranajit. 1997. Dominance without Hegemony: History and Power in Colonial India. Cambridge, MA: Harvard University Press.

Hollander, Edwin P. 2009. Inclusive Leadership: The Essential Leader-Follower Relationship. New York: Routledge.

Laclau, Ernesto. 2005. On Populist Reason. London: Verso.

Lacoue-Labarthe, Philippe. 1989. “Diderot: Paradox and Mimesis.” In Typography: Mimesis, Philosophy, Politics, ed. Christopher Fynsk, 248-266. Stanford, CA: Stanford University Press.

Lacoue-Labarthe, Philippe. 1990. Heidegger, Art, and Politics: The Fiction of the Political. Trans. Chris Turner. Oxford: Basil Blackwell.

Lacoue-Labarthe, Philippe, and Jean-Luc Nancy. 1997. "The 'Retreat' of the Political.” In Retreating the Political, ed. Simon Sparks, 117-132. London: Routledge.

Lander, Edgardo. 1996. "The Impact of Neoliberal Adjustment in Venezuela, 1989-1993.” Trans. Luis A. Fierro. Latin American Perspectives 23 (3): 50-73.

Luigino Bracci, Roa. 2017. "Presidente Maduro celebra resultados de elecciones de Constituyentes desde plaza Bolívar” [President Maduro celebrates the results of 
the Constituent elections.” YouTube video, 48:58 min., 31 July. https://www. youtube.com/watch? $\mathrm{v}=$ CUyu5WHyO0k.

Mazzarella, William. 2019. “The Anthropology of Populism: Beyond the Liberal

Settlement.” Annual Review of Anthropology 48: 45-60.

Naas, Michael. 2015. The End of the World and Other Teachable Moments: Jacques Derrida's Final Seminar. New York: Fordham University Press.

Nancy, Jean-Luc. 2000. Being Singular Plural. Trans. Robert Richardson and Anne O’Bryne. Stanford, CA: Stanford University Press.

Reuters Staff. 2017. "Venezuelan Election Turnout Figures Manipulated by One Million Votes: Election Company.” Reuters, 2 August. https://www.reuters. com/article/us-venezuela-politics-vote-smartmatic-idUSKBN1AI1KZ?il = 0 .

Reuters Staff. 2020. "Trump Suggests Governors Call in National Guard to 'Dominate the Streets,'” Reuters, 6 June. https://www.reuters.com/article/ minneapolis-police-protests-trump-idINKBN23D08M.

Roberts, Kenneth. 2003. "Social Polarization and the Populist Resurgence in Venezuela.” In Venezuelan Politics in the Chávez Era: Class, Polarization, and Conflict, ed. Steve Ellner and Daniel Hellinger, 55-72. Boulder, CO: Lynne Rienner.

Rosales, Antulio. 2017. "Venezuela's Deepening Logic of Extraction." NACLA Report on the Americas 49 (2): 132-135.

Sánchez, Rafael. 2001. "Channel Surfing: Media, Mediumship, and State Authority in the María Lionza Possession Cult (Venezuela)." In Religion and Media, ed. Hent de Vries and Samuel Weber, 388-434. Stanford, CA: Stanford University Press.

Sánchez, Rafael. 2008. "Seized by the Spirit: The Mystical Foundation of Squatting among Pentecostals in Caracas (Venezuela) Today.” Public Culture 20 (2): 267-305.

Sánchez, Rafael. 2016. Dancing Jacobins: A Venezuelan Genealogy of Latin American Populism. New York: Fordham University Press.

Taussig, Michael. 1997. The Magic of the State. New York: Routledge.

Vásquez Lezama, Paula. 2014. Le chavisme: Un militarisme compassionnel

[Chavism: A compassionate militarism]. Paris: Maison des Sciences de l'Homme.

Vásquez Lezama, Paula. 2016. "Franklin Brito: El cuerpo como protesta” [Franklin Brito: The body as protest]. Letras Libres 208: 48-50. https://www.letraslibres. com/sites/default/files/filess6/files/perfil-vasquez-esp.pdf.

Zakaria, Fareed. 2003. The Future of Freedom: Illiberal Democracy at Home and Abroad. New York: W. W. Norton. 